\title{
Ghosting Pasca Peminangan/Khitbah Menurut Hukum Perdata Indonesia dan Hukum Islam
}

\author{
Aufi Imaduddin, Mir'atul Firdausi, Tiyan Iswahyuni \\ Institut Agama Islam Nahdlatul Ulama Tuban \\ E-mail: aufiabuzaya@gmail.com, fiersmiror@gmail.com, \\ tiyaniswahyuni@gmail.com
}

\begin{abstract}
Abstrak: Ghosting dapat diartikan mengakhiri hubungan secara mendadak dalam percintaan maupun pertemanan. Dalam percintaan para remaja yang menjalin hubungan atau pacaran seringkali mengalami dijanjikan untuk dinikahi tetapi janji tersebut tidak ditepati. Janji menikahi ini berbeda dengan perjanjian perkawinan sebagaimana dalam UndangUndang nomor 1 tahun 1975 tentang perkawinan, janji menikahi yang dianggap sebagai ghosting ini disampaikan lewat lisan berupa rayuan, bahkan ada yang merayu untuk berhubungan badan dengan janji untuk dinikahi namun kemudian mengingkari janji tersebut dan menghilang begitu saja padahal persiapan pernikahan sudah 90 persen. Kejadian ini sudah banyak terjadi dari dahulu hingga saat ini. Dalam hukum perdata, ghosting yang menyebabkan pembatalan lamaran atau pinangan tidak menimbulkan hak untuk menuntut berlangsungnya perkawinan kepada pengadilan, juga tidak ada hak untuk menuntut ganti rugi biaya akibat tidak dipenuhinya janji menikahi yang dilakukan oleh pelaku, akan tetapi ganti rugi bisa dituntut ketika sudah ada pengumuman tentang perkawinan tersebut dalam tenggang waktu delapan belas bulan terhitung dari pengumuman perkawinan. Sama halnya dalam hukum Islam ghosting yang menyebabkan pembatalan khitbah juga tidak mengikat dan tidak ada konsekuensi apapun sebelum adanya akad nikah, namun pembatalan lamaran atau khitbah harus dengan tata cara yang baik sesuai dengan tuntutan kebiasaan agar bisa saling menjaga kehormatan dan silaturrahim masing-masing.

Kata Kunci: Ghosting, hukum perdata Indonesia, hukum Islam.
\end{abstract}

\section{Pendahuluan}

Istilah ghosting begitu populer dikalangan remaja Indonesia khususnya bagi yang aktif dimedia sosial. Ghosting berasal dari kata ghost (bahasa inggris) yang artinya hantu. ${ }^{1}$ Ghosting sendiri artinya

${ }^{1}$ Merriam webster, Dictionary Merriam Webster, (Incorporated,2006), hlm.178 
berbayangan. Dalam kamus Mariam webster mendefinisikan ghosting dalam arti informal adalah the act or practice of abruptly cutting of all contact with someone (such as a former romantic partner) by no longer accepting or responding to phone calls, instant messages, etc. praktik mengakhiri hubungan pribadi dengan seseorang dengan tiba-tiba dan tanpa penjelasan menarik diri dari semua komunikasi.

Ghosting bisa diartikan mengakhiri hubungan secara mendadak dalam percintaan maupun pertemanan. Dalam percintaan para remaja yang menjalin hubungan atau pacaran seringkali mengalami dijanjikan untuk dinikahi tetapi janji tersebut tidak ditepati. Janji menikahi ini berbeda dengan perjanjian perkawinan sebagaimana dalam Undang-Undang nomor 1 tahun 1975 tentang perkawinan, janji menikahi yang dianggap sebagai ghosting ini disampaikan lewat lisan berupa rayuan, bahkan ada yang merayu untuk berhubungan badan dengan janji untuk dinikahi namun kemudian mengingkari janji tersebut dan menghilang begitu saja padahal persiapan pernikahan sudah 90 persen, mulai biaya catering, sewa gedung dan lain-lain. Dan kejadian ini sudah banyak terjadi dari dahulu hingga saat ini.

Perilaku pelaku ghosting memberi kesan bahwa ia merupakan seorang pengecut yang tidak bertanggung jawab secara moral, meninggalkan korban tanpa memberikan suatu alasan yang jelas memberikan beban mental dan psikologis terhadap korban. Selain itu tindakan pelaku juga merupakan bentuk pelanggaran hukum yang dapat dimintai pertanggungjawabannya secara hukum. Pihak yang dirugikan bisa menggugat si pelaku baik dalam jalur perdata maupun jalur pidana. Jika melalui jalur perdata korban harus menghitung nilai kerugian baik kerugian materiil maupun immateriil, ${ }^{2}$ jika melalui jalur pidana bisa disesuaikan dengan peristiwa yang dialami, misal pasal 378 KUHP tentang penipuan ${ }^{3}$ atau bisa dengan pasal pidana lainnya.

Dalam jalur perdata terdapat dua dasar gugatan yaitu wanprestasi dan perbuatan melawan hukum. Wanprestasi/ingkar janji adalah suatu perbuatan yang tidak memenuhi janji atau prestasi yang sudah disepakati

\footnotetext{
2 Pasal 1365 Kitab Undang-Undang Hukum Perdata

3 "Barang siapa dengan maksud untuk menguntungkan diri sendiri atau orang lain secara melawan hukum dengan memakai nama palsu atau martabat palsu dengan tipu muslihat ataupun rangkaian kebohongan menggerakkan orang lain untuk menyerahkan barang sesuatu kepadanya, atau supaya memberi hutang maupun menghapuskan piutang diancam karena penipuan dengan pidana penjara paling lama empat tahun"
} 
oleh para pihak, sedangkan perbuatan melawan hukum adalah perbuatan yang melanggar ketentuan hukum, baik hukum tertulis maupun hukum tidak tertulis yaitu perbuatan yang bertentangan dengan kesusilan atau kepatutan di masyarakat. Namun dari dua dasar gugatan tersebut, perbuatan ghosting atau ingkar janji harus memenuhi unsur-unsur masing-masing gugatan. Dalam dasar gugatan perbuatan melawan hukum unsur-unsur yang harus dipenuhi yaitu adanya suatu perbuatan, perbuatan itu melawan hukum, adanya kesalahan dari pihak pelaku, adanya kerugian bagi korban dan adanya hubungan kausal antara perbuatan dengan kerugian. Adapun unsur-unsur yang harus dipenuhi dalam gugatan wanprestasi adalah Adanya kesepakatan yang mengikat dirinya, Adanya kecakapan untuk membuat suatu perikatan, Adanya suatu pokok persoalan tertentu, Adanya suatu sebab yang tidak terlarang. Beberapa contoh kasus ghosting atau ingkar janji menikahi di Indonesia adalah sebagai berikut:

1. Gagal menikah karena calon ditolak keluarga (1986)

Peristiwa terjadi di Nusa Tenggara Barat, yang menjadi titik permasalahan adalah tidak terlaksananya janji pernikahan yang diucapkan oleh IGLR (laki-laki) terhadap MDI (perempuan). IGLR menjanjikan nikah kepada MDI karena dia sangat mencintainya dan menyerahkan kartu taspen, kartu pegawai dan sepeda motor baru sebagai bukti cinta, mereka pun hidup bersama selama lebih dari setahun dan biaya hidup bersama banyak ditanggung oleh MDI. Walaupun sudah hidup bersama, janji adanya pernikahan pun belum terlaksana dengan dalih bahwasanya IGLR akan dibuang keluarganya jika menikah dengan MDI. MDI memutuskan hubungan mereka dan menyeret kasus ini ke pengadilan, ia meminta agar IGLR ganti rugi atas biaya hidup bersama yang telah dikeluarkan sebanyak hampir 1,5 juta dan menuntut ganti rugi sebanyak 5 juta untuk pemulihan nama baik karena ia harus menanggung malu.

Pengadilan Negeri Mataram memutuskan mengabulkan sebagian gugatan MDI dan menyatakan tergugat tidak menepati janji untuk menikahi penggugat serta menghukum tergugat untuk membayar 2,5 juta sebagai pemulihan nama baik penggugat. Namun pengadilan Tinggi mengabulkan permohonan tergugat dan menolak seluruh gugatan MDI. 2 tahun kemudian Majelis hakim Agung memenangkan putusan banding dan mengadili sendiri perkara tersebut, serta 
menyatakan bahwa tergugat telah terbukti melakukan perbuatan melawan hukum dan oleh karena itu dibebani ganti rugi 2,5 juta sebagai pemulihan nama baik. ${ }^{4}$

2. Ingkar janji menikahi, melanggar kesusilaan dan kepatutan (2003)

HWN (laki-laki) menyatakan cinta dan keseriusannya untuk menikahi WTW (perempuan) dan menyampaikan niat tersebut kepada orang tua WTW. Karena jarak rumah HWN jauh, orangnya beritikad baik dan sering mengucapkan demi Allah tidak akan meninggalkan WTW, orang tua WTW memperbolehkan HWN untuk tidur di rumah WTW, dan terjadilah hubungan layaknya suami istri. Lambat laun, gelagat dari HWN berubah, setiap kali ditanya tentang tanggal pernikahan dia menjawab tidak bisa berfikir dan meminta untuk tidak dihubungi lagi. Kemudian HWN memutuskan komunikasi secara sepihak, berbagai upaya baik-baik telah diusahakan WTW namun tidak pernah digubris oleh HWN, akhirnya WTW mengambil jalur hukum untuk meminta pertanggungjawaban HWN, ia meminta pengadilan menyatakan HWN telah melakukan perbuatan melawan hukum dan dalam persidangan tersebut HWN pun mengajukan gugatan balik (rekonvensi) karena menganggap penggugat mencemarkan nama baik.

Kemudian pengadilan negeri Surabaya memutuskan untuk mengabulkan permohonan penggugat sebagian dan menyatakan bahwa tergugat tidak menepati janji untuk menikahi penggugat, oleh karena itu tergugat harus membayar ganti rugi biaya hidup yang sudah dikeluarkan oleh penggugat selama hidup bersama sebesar 7,5 juta Rupiah ditambah 10 juta Rupiah untuk pemulihan nama baik. Pengadilan tinggi Surabaya menguatkan hal ini. ${ }^{5}$

3. Ingkar janji menikahi, bayar 2 juta perbulan (2011)

DNA (laki-laki) adalah seorang aparat penegak hukum menjalin hubungan asmara dengan ERC (perempuan) dengan sepengetahuan keluarga ERC. Bahkan DNA tinggal di rumah keluarga ERC, dari hubungan itu lahirlah 2 orang anak padahal keduanya belum melaksanakan perkawinan yang sah. Akan tetapi mereka sudah berencana menikah dan DNA sudah diberikan atasannya untuk menikah, sebelum pernikahan tersebut terlaksana DNA ketahuan

4Putusan Mahkamah Agung Nomor 3191 K/Pdt/1984

5Putusan Mahkamah Agung Nomor 3277 K/Pdt/2000 
menikah dengan perempuan lain. ERC pun merasa dirugikan dan menempuh upaya hukum ke pengadilan negeri Merauke, dalam gugatannya ia menyatakan bahwa ingkar janji menikah berdampak buruk terhadap psikologinya dan anak-anak butuh biaya hidup. ERC meminta pengadilan untuk menghukum DNA dengan membayar biaya hidup anak-anak tersebut dan ganti rugi atas ingkar janji menikah.

Namun pengadilan negeri Merauke menyatakan tidak dapat menerima gugatan ERC, kemudian pengadilan tinggi Jayapura mengabulkan gugatan penggugat sebagian yang menyatakan bahwa tergugat telah melakukan wanprestasi karena ingkar janji menikah dan menghukum tergugat dengan membayar ganti rugi sebesar 100 juta Rupiah. Melalui permohonan kasasi, Mahkamah Agung (salah satu hakim agung yang memutus perkara ini adalah Artidjo Alkostar) memutuskan untuk menghukum tergugat dengan membayar biaya keuangan dan tuntutan hukum untuk membayar biaya pernikahan dan hubungan dua anak yang sah sebesar 2 juta rupiah per bulan 18 tahun, tergugat harus membayar paling lambat tanggal 5 setiap bulan. Indonesia merupakan sebuah negara yang penduduknya mayoritas beragama Islam memiliki aturan praktis hukum Islam yang menghimpun berbagai hasil ijtihad para ulama klasik maupun kontemporer, himpunan hukum Islam tersebut dinamakan Kompilasi Hukum Islam (HKI). Pembatan lamaran/peminangan atau disebut khitbah juga diatur dalam KHI, yaitu dalam Pasal 13 ayat 1 dan 2:

Ayat 1: "pinangan belum menimbulkan akibat hukum dan para pihak bebas memutuskan hubungan pinangan"

Ayat 2: "Kebebasan memutuskan hubungan peminangan dilakukan dengan tata cara yang baik sesuai dengan tuntutan dan kebiasaan setempat, sehingga tetap terbina kerukunan dan saling menghargai"

Pembatalan peminangan/khitbah diperbolehkan dalam Islam, namun dengan catatan dilakukan dengan cara yang baik-baik sesuai tuntutan dan kebiasaan setempat agar tetap terbina kerukunan. Ali bin Abi Thalib pun pernah membatalkan lamarannya karena melamar anak Abu Jahal.

عن الزهري قال حدثني علي بن حسين أن المسور بن مخرمة قال إن عليا خطب بنت أبي جهل فسمعت بذلك فاطمة فأتت رسول الله ثلى الله عليه وسلم فقالت يزعم قومك أنك لا تغضب لبناتلك وهذا علي ناكح بنت أبي جهل فقام رسول الله فسمعته حين تشهد يقول أما بعد أنكحت أبا العاص بن ربيع فحدثني 


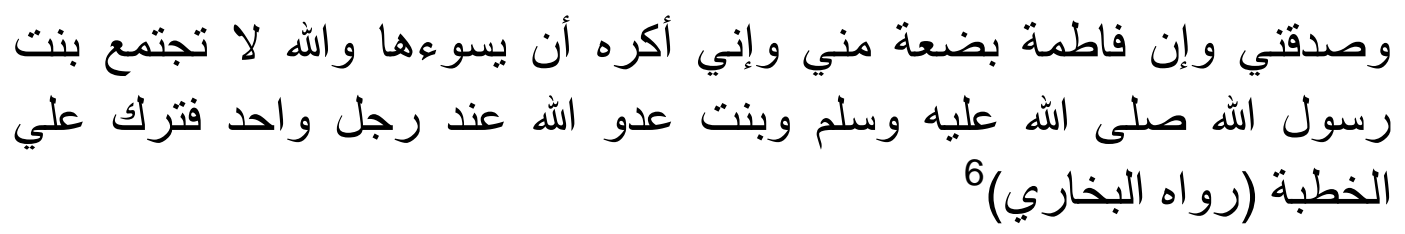

Dari Az Zuhriy berkata, telah bercerita kepadaku Ali bin Husain bahwa Al Miswar bin Makhramah berkata: Ali pernah meminang putri Abu Jahal, lalu hal itu didengar oleh Fathimah. Maka Fathimah menemui Rasulullah SAW dan berkata: "kaummu berkata bahwa baginda tidak marah demi putri baginda. Sekarang Ali hendak menikahi putri Abu Jahal". Maka Rasulullah SAW berdiri dan aku mendengar ketika beliau bersyahadat bersabda: "Hadirin, aku telah menikahkan Abu Al 'Ash bin Ar Rabi' lalu dia berkomitmen kepadaku dan sesungguhnya Fathimah adalah bagian dari diriku dan sungguh aku tidak suka bila ada orang yang menyusahkannya. Demi Allah, tidak akan berkumpul putri Rasulullah SAW dan putri dari musuh Allah pada satu orang laki-laki". Maka Ali membatalkan pinangannya (HR. Bukhari)

Agama Islam pun melarang perbuatan ghosting karena dianggap memutuskan hubungan silaturahmi dan hal tersebut dilarang oleh Islam. Dari Anas bin Malik bahwasanya Rasulullah SAW bersabda: "janganlah kalian saling membenci, saling hasad (dengki), saling membelakangi. Dan jadilah kalian hamba-hamba Allah yang bersaudara, tidak dihalalkan bagi seorang muslim menjauhi saudaranya lebih dari tiga hari" (muttafaq ‘alaih).

Apalagi ghosting yang termasuk mengingkari janji menikahi atau membatalkan khitbah secara sepihak tanpa adanya alasan yang rasional dan itikad tidak baik. Perbuatan ingkar janji adalah perbuatan yang tercela dan termasuk golongan orang-orang yang munafik

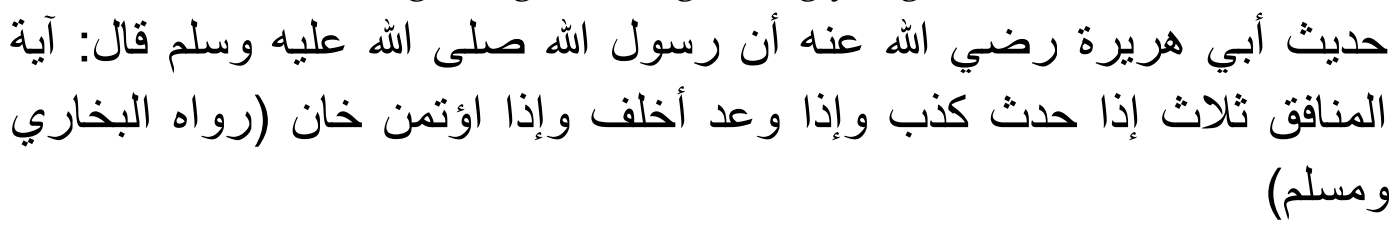

“Tanda Orang munafik ada tiga: apabila berkata ia berbohong, apabila berjanji mengingkari dan bila dipercaya mengkhianati" (HR. Bukhari dan Muslim).

Dari pemaparan diatas maka penulis akan meniliti, bagaimana hukum ghosting dan akibat hukumya pasca peminangan/khitbah menurut hukum perdata Indonesia dan hukum Islam?.

${ }^{6}$ Imam Abi 'Abdillah Muhammad bin Ismail Al Bukhari, Shahih Bukhari, (Mesir: Daar alHadits), hlm. 69/12 


\section{Ghosting dalam Hukum Perdata}

Istilah Ghosting tidak dikenal dalam hukum, apalagi dalam hubungan pacaran. Karena pacaran tidak menimbulkan peristiwa, perbuatan dan akibat hukum. Jadi tidak hak dan kewajiban yang timbul pada orang yang berpacaran, jika ada pihak yang dirugikan maka tidak dapat menuntut kewajiban kepada pihak lain untuk bertanggung jawab. Misal: laki-laki yang berjanji untuk menikahi perempuan namun setelah itu tidak menepati janjinya dan menghilang begitu saja tanpa kabar apapun, maka perempuan tersebut tidak bisa menuntut ke ranah hukum.

Pasal 58 Kitab Undang-Undang Hukum Perdata menyebutkan bahwa: “janji kawin tidak menimbulkan hak untuk menuntut di muka hakim berlangsungnya perkawinan, juga tidak menimbulkan hak untuk menuntut penggantian biaya, kerugian dan bunga, akibat tidak dipenuhinya janji itu, semua persetujuan untuk ganti rugi dalam hal ini adalah batal. Akan tetapi, jika pemberitahuan kawin ini telah diikuti oleh suatu pengumuman, maka hal itu dapat menjadi dasar untuk menuntut penggantian biaya, kerugian dan bunga berdasarkan kerugian-kerugian yang nyata diderita oleh satu pihak atas barang-barangnya sebagai akibat dan penolakan pihak yang lain, dalam pada itu tidak boleh diperhitungkan soal kehilangan keuntungan. Tuntutan ini lewat waktu dengan lampaunya waktu delapan belas bulan terhitung dari pengumuman perkawinan". ${ }^{7}$

Pasal tersebut merumuskan tiga hal: Pertama, janji menikahi tidak menimbulkan hak untuk menuntut di muka hakim untuk dilangsungkan perkawinan. Juga tidak menimbulkan hak untuk menuntut penggantian biaya, kerugian, dan bunga, akibat tidak dipenuhinya janji itu. Semua persetujuan ganti rugi dalam hal ini adalah batal. Kedua, namun jika pemberitahuan nikah telah diikuti suatu pengumuman, maka hal ini dapat menjadi dasar untuk menuntut kerugian. Ketiga, masa daluarsa untuk menuntut ganti rugi tersebut adalah 18 bulan terhitung sejak pengumuman rencana perkawinan.

Namun ada beberapa kasus ghosting yang masuk dalam pengadilan dengan perkara ingkar janji menikahi. janji menikahi ini berbeda dengan perjanjian perkawinan sebagaimana dikenal dalam Undang-Undang (UU) 1 Tahun 1975 tentang Perkawinan. Janji menikahi ini biasanya disampaikan secara lisan, bahkan mungkin rayuan. Salah satu contoh

${ }^{7}$ Kitab Undang-Undang Hukum Perdata/BW 
perkara yang baru terjadi adalah putusan kasasi MA Nomor 1644 K/Pdt/2020. Dalam putusan tersebut Mahkamah Agung menolak kasasi tergugat dan menyetujui putusan pengadilan tinggi dengan membayar denda 150 juta secara tunai dan sekaligus. penggugat melaporkan tergugat yang mengingkari janjinya untuk menikahi dengan dalih perbuatan melawan hukum yang merugikan penggugat baik secara materil maupun immateril. Ingkar janji menikahi dapat masuk kedalam kategori perbuatan melawan hukum karena melanggar norma kesusilaan dan kepatutan di masyarakat. ${ }^{8}$

Jika kita lihat pasal mengenai perbuatan melawan hukum yakni pasal 1365 KUHPER “Tiap perbuatan yang melanggar hukum dan membawa kerugian kepada orang lain, mewajibkan orang yang menimbulkan kerugian itu karena kesalahannya untuk menggantikan kerugian tersebut" ada 4 unsur yang harus dipenuhi yaitu:

1. Ada perbuatan melawan hukum yaitu perbuatan yang mengakibatkan kegoncangan dalam neraca keseimbangan masyarakat baik berupa pelanggaran peraturan-peraturan hukum, kesusilaan, keagamaan dan sopan santun dalam masyarakat.

2. Ada kesalahan yaitu kesengajaan pelaku menjanjikan perkawinan tersebut dengan keadaan sadar sepenuhnya tentang akibat dari perbuatannya dan ia harus bertanggungjawab akan hal tersebut.

3. Ada kerugian yaitu, bentuk ganti rugi dalam hukum adalah":

a. Ganti rugi nominal, jika ada perbuatan hukum serius seperti yang mengandung unsur kesengajaan tetapi tidak menimbulkan kerugian yang nyata bagi si korban, maka bisa diberikan sejumlah uang tertentu sesuai dengan rasa keadilan terhadap korban tanpa menghitung berapa sebenarnya kerugian tersebut.

b. Ganti rugi kompensasi/aktual atau disebut juga dengan immateriil, merupakan ganti rugi pembayaran kepada pihak korban sebesar kerugian yang benar-benar telah dialami dari suatu perbuatan melawan hukum, pembayaran tersebut berupa sejumlah uang yang jumlahnya tidak dapat diperhitungkan secara matematis, sesuai dengan kebijaksanaan hakim. Misal ganti rugi atas segala biaya yang sudah dikeluarkan oleh korban,

${ }^{8}$ Yurisprudensi Putusan Mahkamah Agung No. 3191 K/Pdt/1984

${ }^{9}$ Munir fuady, Perbuatan Melawan Hukum Pendekatan Kontemporer, (Bandung: Citra Aditya

Bakti,2010), hlm. 134-135 
penderitaan fisik maupun mental. Jumlah tersebut juga bergantung pada banyak hal ${ }^{10}$, diantaranya beratnya beban mental yang dipikul oleh korban, status dan kedudukan korban, situasi dan kondisi mental dari pelaku, latar belakang dilakukannya perbuatan melawan hukum, jenis perbuatan melawan hukum yakni kesengajaan, kelalaian atau tanggungjawab mutlak.

c. Ganti rugi penghukuman yaitu ganti rugi dalam jumlah besar yang melebihi dari jumlah kerugian yang sebenarnya. Besarnya jumlah tersebut sebagai hukuman bagi si pelaku.

4. Ada hubungan kausal antara kerugian dengan perbuatan.

Bujuk rayu berupa janji kawin membuat si korban menuruti keinginan pelaku, kerugian yang paling nyata diderita oleh si korban adalah rusaknya kehormatan dan nama baiknya di masyarakat. Dengan mengguggat sipelaku maka nama baik dan kehormatannya dapat dipulihkan. Pasal 58 ayat 2 KUHPER menyatakan "jika pemberitahuan kawin ini telah diikuti oleh suatu pengumuman, maka hal itu dapat menjadi dasar untuk menuntut penggantian biaya, kerugian dan bunga berdasrkan kerugian-kerugian yang nyata di derita oleh satu pihak atas batang-barangnya sebagai akibat penolakan pihak yang lain, dalam pada itu tak boleh diperhitungkan soal kehilangan keuntungan". Dengan demikian, tindakan membatalkan janji kawin yang sudah diumumkan dan diberitahukan kepada pegawai pencatat nikah merupakan perbuatan melawan hukum dan pihak yang dirugikan dapat menuntut ganti rugi.

Dasar gugatan perdata lain tentang perjanjian selain perbuatan melawan hukum adalah dengan gugatan wanprestasi yaitu suatu perbuatan yang dari seseorang yang tidak memenuhi janji atau prestasinya sebagaimana yang sudah disepakati para pihak. Pasal 1267 KUH Perdata menyatakan "pihak yang terhadapnya perikatan tidak dipenuhi, dapat memilih, memaksa pihak yang lain untuk memenuhi persetujuan, jika hal itu masih dapat dilakukan atau menuntut pembatalan persetujuan dengan penggantian biaya, kerugian atau bunga". Berarti korban dapat menuntut pemenuhan prestasi atau perjanjian perkawinan yang sudah dijanjikan, dan pengingkaran terhadap hal tersebut merupakan wanprestasi.

Namun hal tersebut harus sesuai dengan unsur-unsur syarat sahnya perjanjian sehingga perjanjian tersebut mengikat para pihak yang

${ }^{10}$ Munir Fuady, hlm. 142-143 
membuatnya. Sebagaimana syarat yang ditentukan pasal 1320 KUH Perdata yaitu:

1. Adanya kesepakatan yang mengikat dirinya, janji nikah merupakan kesepakatan antarakedua belah pihak dan hal ini memenuhi unsur syarat sahnya perjanjian.

2. Adanya kecakapan untuk membuat suatu perikatan, unsur ini pun memenuhi syarat sahnya perjanjian karena perjanjian pernikahan disepakati oleh orang yang cakap yaitu sudah dewasa, jika yang bersepakat orang dibawah umur maka diwakili oleh orang tua atau wali.

3. Adanya suatu pokok persoalan tertentu. Persoalan tertentu dilihat dari objek perjanjian yakni hanya barang yang dapat diperdagangkan saja yang dapat menjadi pokok persetujuan ${ }^{11}$ dan obyek yang dilarang undang-undang. Janji nikah tidak memenuhi unsur ini karena bukan merupakan barang yang bisa diperdagangkan melainkan tentang hubungan personal dalam hukum keluarga. Jadi ingkar janji menikahi bukan termasuk wanpestasi.

4. Adanya suatu sebab yang tidak terlarang, Janji nikah adalah hal yang tidak dilarang undang-undang, namun apabila janji nikah diingkari dan ada korban yang mengalami kerugian materiil maupun immateriil maka korban berhak mengguggat si pelaku, tapi bukan dengan dasar gugatan wanprestasi karena tidak sesuai dengan pasal 58 ayat 1 KUHPer.

Maka dari itu ingkar dalam janji menikahi bisa digugat dengan dasar gugatan perbuatan melawan hukum bukan dengan dasar gugatan wanprestasi karena tidak memenuhi unsur-unsur syarat sahnya perjanjian.

\section{Ghosting dalam Hukum Islam}

Pernikahan harus berdiri dengan fondasi dan prinsip yang kuat, tahapan untuk menuju pernikahan diantaranya adalah melamar atau mengkhitbah, yaitu cara seorang laki-laki menunjukkan dan mengabarkan keseriusannya untuk menikahi seorang perempuan dengan mendatangi keluarga perempuan. Penyampaian niat tersebut bisa disampaikan langsung oleh si laki-laki atau melalui wakilnya, jika si perempuan menerima maka tahapan-tahapan lain menuju pernikahan akan

${ }^{11}$ Pasal 1332 KUHPER 
dilanjutkan, jika tidak maka tahapan pernikahan berhenti disini. Sebagaimana firman Allah dalam surat al-Baqarah ayat 235.

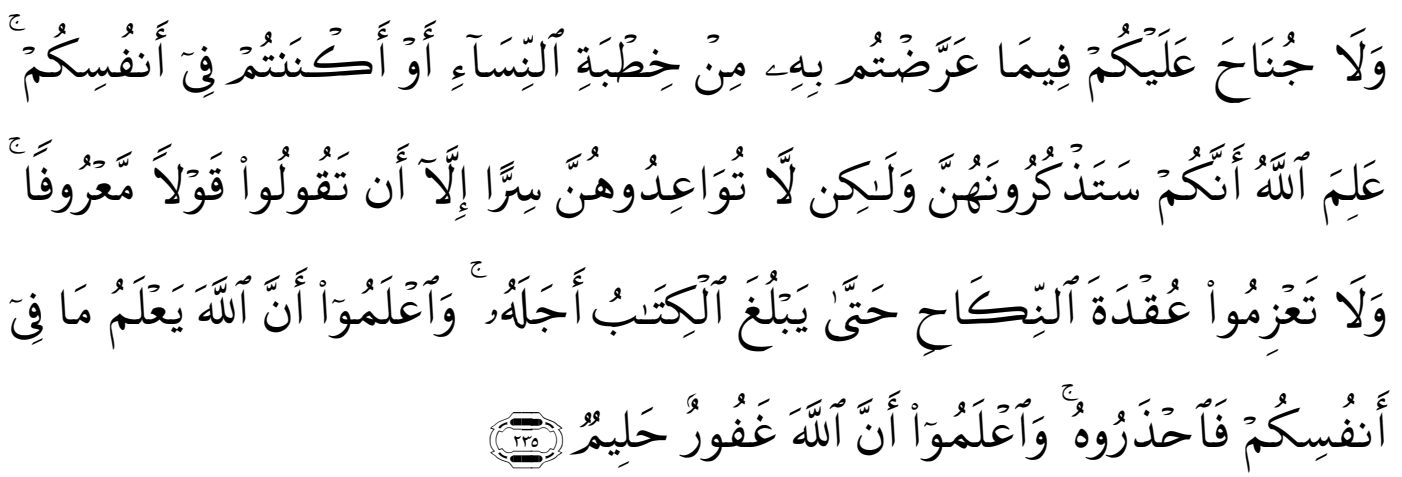

Artinya "Dan tidak ada dosa bagi kamu meminang wanita-wanita itu dengan sindiran atau kamu Menyembunyikan (keinginan mengawini mereka) dalam hatimu. Allah mengetahui bahwa kamu akan menyebut-nyebut mereka, dalam pada itu janganlah kamu Mengadakan janji kawin dengan mereka secara rahasia, kecuali sekedar mengucapkan (kepada mereka) Perkataan yang ma'ruf[150]. dan janganlah kamu ber'azam (bertetap hati) untuk beraqad nikah, sebelum habis 'iddahnya. dan ketahuilah bahwasanya Allah mengetahui apa yang ada dalam hatimu; Maka takutlah kepada-Nya, dan ketahuilah bahwa Allah Maha Pengampun lagi Maha Penyantun" (QS: Al Baqarah: 235)

Hadis Jabir bin Abdullah riwayat Abu Daud:

عن جابر بن عبداله صلى الله عليه وسلم قال: إذا خطب أحدكم المرأة فان استطاع أن ينظر إلى ما يدعوه إلى نكاحها فليفعل (رواه أبو داود)

Artinya: "Apabila seseorang diantara kamu meminang seorang perempuan, jika ia dapat melihat apa yang dapat mendorongnya semakin kuat untuk menikahinya, maka laksanakanlah (HR. Abu Daud)

Tujuan diadakannya lamaran atau khitbah adalah memudahkan perkenalan antara kedua belah pihak keuarga, menumbuhkan rasa kasih sayang, memanfaatkan momen ini secara maksimal untuk mengenal lebih jauh pasangan yang akan dinikahi dan menimbulkan ketentraman jiwa karena sudah saling cocok dan dan yakin dengan calon pasangan hidupnya. ${ }^{13}$ Khitbah atau lamaran disini adalah sekedar perjanjian untuk menikah dan bukan pernikahan itu sendiri. Seperti yang dikemukakan

\footnotetext{
${ }^{12}$ Imam Hafiz Al Mushannif Al muttaqin Abi Daud Sulaiman, Sunan Abu Daud, (Beirut: Daar Ibn Hazm, 202H), Jilid II, hlm. 480

${ }^{13}$ Abd. Nashir Taufiq, Saat Anda Meminang, (Jakarta: Pustaka Azzam, 2001), hlm. 19-21.
} 
Wahbah Az Zuhayli:

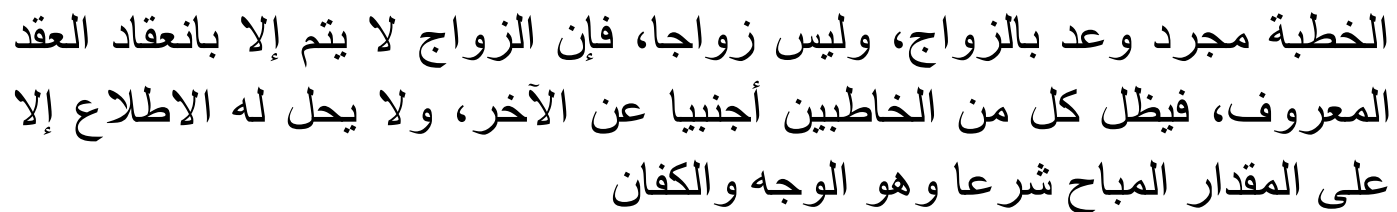

Artinya: " Khitbah itu baru sekadar janji pernikahan bukan pernikahan. Sebab, pernikahan tak terlaksana kecuali dengan sahnya akad yang sudah maklum. Dengan begitu, laki-laki yang melamar dan perempuan yang dilamar statusnya masih orang lain. Tidak halal bagi si pelamar untuk melihat si perempuan kecuali bagian yang diperbolehkan syariat, yakni wajah dan kedua telapak tangan" ${ }^{14}$

Jadi, jika suatu saat salah satu dari pasangan berpaling dari lamaran atau khitbah tersebut dengan berbagai pertimbangan maka tidak ada konsekuensi hukum apapun selama belum terjadinya akad nikah. Namun pembatalan lamaran harus dengan alasan yang rasional dan harus dengan tindakan dan perkataan yang hati-hati karena jika tidak akan berimbas terhadap masalah sosial seperti kehormatan, nama baik dan lain sebagainya.

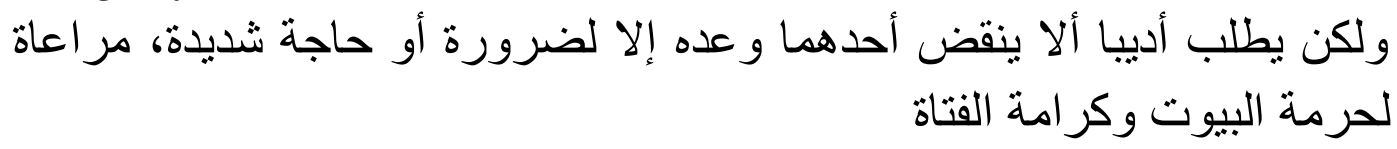

"Akan tetapi, dianjurkan sebagai bentuk etika bagi salah satunya, untuk tidak merusak janjinya, kecuali dalam keadaan yang mendesak atau kebutuhan yang sangat. (hal itu) demi menjaga kehormatan keluarga dan kemuliaan perempuan" ${ }^{15}$

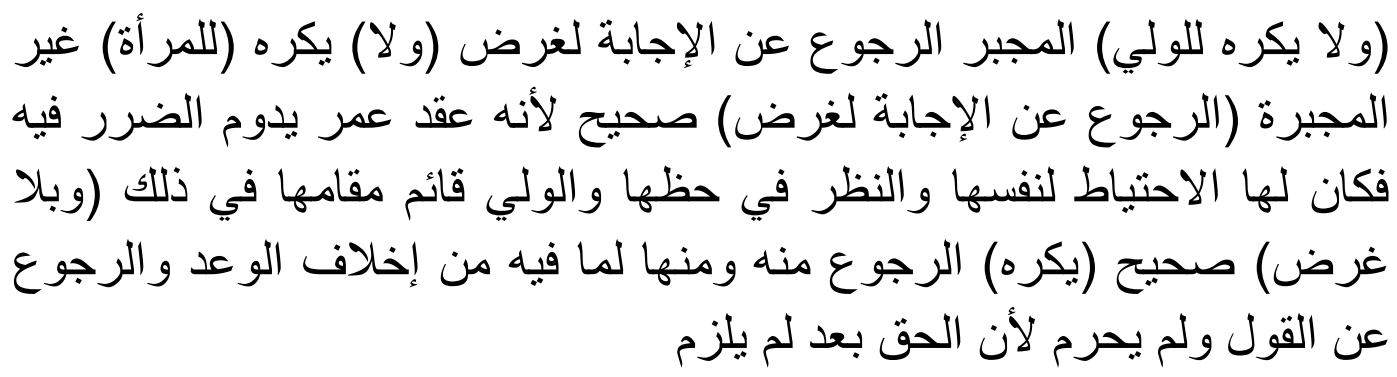

“Tidak dimakruhkan bagi pihak wali yang memiliki kuasa atas perempuan untuk menarik kembali lamaran yang sudah disetujui sebab sebuah tujuan. Tidak pula dimakruhkan bagi perempuan yang independen. Keduanya itu jika dengan tujuan yang dibenarkan. Sebab pernikahan merupakan ikatan berkelanjutan yang dampaknya akan

${ }^{14}$ Wahbah Zuhayli, Al Fiqhul Islami wa Adilatuhu IX (Damaskus: Daar al-Fikri,1404), hlm. 64-93.

${ }^{15}$ Wahbah Zuhayli, hlm. 19 
dirasakan selamanya, maka seorang perempuan atau wali bisa lebih berhati-hati dalam mempertimbangkannya. Dan bila tanpa ada tujuan yang dibenarkan, maka dimakruhkan menarik kembali dari lamaran yang sudah disetujui. Sebab hal ini termasuk bentuk pengingkaran terhadap janji ataupun menarik kembali kata-kata yang telah terucap. Namun tidak sampai mencapai taraf haram, sebab hak yang ada dalam lamaran yang telah disetujui itu bukanlah hak yang mengikat" 16

Dipertegas dalam KHI Pasal 13 ayat 2: "Kebebasan memutuskan hubungan peminangan dilakukan dengan tata cara yang baik sesuai dengan tuntutan agar dan kebiasaan setempat, sehingga tetap terbina kerukunan dan saling menghargai".

Ketika terjadi pembatalan khitbah, tidak dibenarkan untuk mengambil kembali pemberian yang sudah diberikan pada proses khitbah. Rasulullah SAW bersabda: “Tidak halal bagi seorang muslim memberi sesuatu kepada orang lain kemudian memintanya kembali, kecuali pemberian ayah kepada anaknya" (HR Ahmad).

Perbuatan ghosting yang menyebabkan batalnya suatu lamaran adalah perbuatan yang tercela dan tidak rasional, menghilang secara tiba-tiba tanpa kontak sama sekali setelah diadakannya lamaran atau khitbah. Dalam Islam, menghilangkan hubungan dengan orang lain sama halnya dengan memutus tali silaturahim dan itu sangat dilarang oleh Islam. Seperti yang disebutkan dalam hadits:

عن أنس بن مالك رضي الله عنه أن رسول الله صلى الله عليه وسلم قال لا تباغضوا ولا تحاسدوا و لا تدبروا وكونوا عباد الله إخوانا و لا بحلّ لمسلم أن رنه رنه يهجر أخاه فوق ثلاث (متفق عليه)

Dari Anas bin Malik bahwasanya Rasulullah SAW bersabda: janganlah kalian saling membenci, saling hasad (dengki), saling membelakangi. Dan jadilah kalian hamba-hamba Allah yang bersaudara, tidak dihalalkan bagi seorang muslim menjauhi saudaranya lebih dari tiga hari (muttafaq 'alaih).

Memutus hubungan dengan orang lain bukan demi kebaikan orang yang memutus atau yang diputus silaturahimnya tetapi mengakibatkan kerusakan bagi kedua belah pihak, bahkan memutus hubungan silaturahim termasuk dosa besar karena terdapat kerusakan agama dan dunia. "Abu Hurairah, Nabi Muhammad SAW bersabda: orang muslim

${ }^{16}$ Mansur Yunus al buhuti al hanbali, kasyaful iqna' 'an matanil iqna' V, (Saudi Arabia: Daar al- Kutub al-Ilmiyah, 1421), hlm. 20 
tidak boleh memutus hubungan silaturahim lebih dari tiga hari. Barang siapa memutuskan hubungan lebih dari tiga hari kemudian meninggal, maka dia akan masuk neraka (HR. Abu Dawud)". Memutus tali silaturahim adalah memutus kebiasaan kerabat tanpa ada udzur syar'i dan dapat mendatangkan kegelisahan hati dan terasingnya hati ${ }^{17}$

Tidak hanya memutus tali silaturahmi, perbuatan ghosting juga termasuk perbuatan ingkar janji.

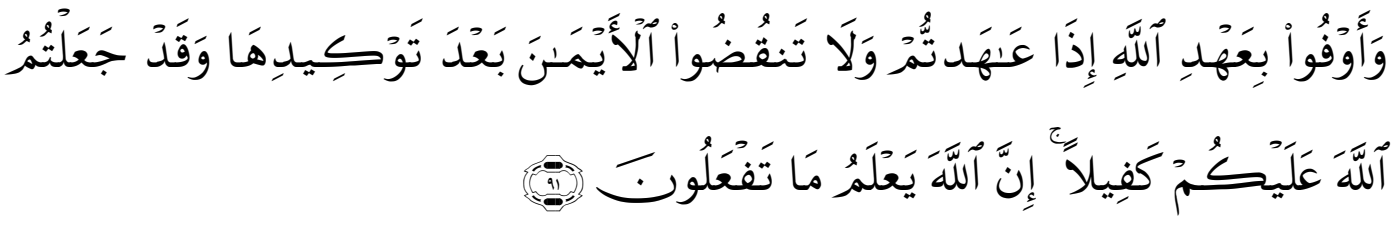

Artinya: “Dan tepatilah Perjanjian dengan Allah apabila kamu berjanji dan janganlah kamu membatalkan sumpah-sumpah(mu) itu, sesudah meneguhkannya, sedang kamu telah menjadikan Allah sebagai saksimu (terhadap sumpah-sumpahmu itu). Sesungguhnya Allah mengetahui apa yang kamu perbuat" (QS: An Nahl:91)

\section{Penutup}

Dalam hukum perdata, ghosting yang menyebabkan pembatalan lamaran atau pinangan tidak menimbulkan hak untuk menuntut berlangsungnya perkawinan kepada pengadilan, juga tidak ada hak untuk menuntut ganti rugi biaya akibat tidak dipenuhinya janji menikahi yang dilakukan oleh pelaku, akan tetapi ganti rugi bisa dituntut ketika sudah ada pengumuman tentang perkawinan tersebut dalam tenggang waktu delapan belas bulan terhitung dari pengumuman perkawinan. Sama halnya dalam hukum Islam ghosting yang menyebabkan pembatalan khitbah juga tidak mengikat dan tidak ada konsekuensi apapun sebelum adanya akad nikah, namun pembatalan lamaran atau khitbah harus dengan tata cara yang baik sesuai dengan tuntutan kebiasaan agar bisa saling menjaga kehormatan dan silaturahim masing-masing.

Hukuman bagi si pelaku ghosting dalam hukum perdata dengan dasar gugatan perbuatan melawan hukum dan memenuhi setiap unsurunsurnya yaitu adanya perbuatan melawan hukum, adanya kesalahan, adanya hubungan kausalitas, dan adanya kerugian ialah si pelaku wajib mengganti kerugian yang telah ditimbulkan oleh pelaku dan dalam hukum Islam tidak ditetapkan hukuman materi seperti di hukum perdata

${ }^{17}$ Habib Abdullah bin Husain bin Thahir ba'lawi, Is'ad Ar rafiq 2, (Haramain: Daarul Ilmi), hlm. 117 
melainkan dianggap suatu perbuatan tercela dan termasuk dalam golongan orang-orang munafik.

\section{Daftar Pustaka}

Kitab Undang-Undang Hukum Perdata

Putusan Mahkamah Agung Nomor 3191 K/Pdt/1984

Putusan Mahkamah Agung Nomor 3277 K/Pdt/ 200

Abdullah Nashir Taufiq. Saat Anda Meminang. Jakarta: Pustaka Azzam. 2001.

Habib Abdullah bin Husain bin Thahir Ba'lawi. Is'ad Ar rafiq 2. Haramain: Daar al-Ilmi.

Imam Abi 'Abdillah Muhammad bin Ismail Al-Bukhari. Shahih Bukhari. Mesir: Daar al-Hadits.

Imam Hafiz Al Mushannif Al-Muttaqin Abi Daud Sulaiman. Sunan Abu Daud. Beirut: Daar Ibn Hazm. 202 H.

Mansur Yunus al-Buhuti Al-Hanbali. Kasyaful iqna' 'an matanil iqna' $V$. Saudi Arabia: Daar al-Kutub al-Ilmiyah. 1421.

Merriam Webster. Dictionary Merriam Webster. Incorporated. 2006.

Munir Fuady. Perbuatan Melawan Hukum Pendekatan Kontemporer. Bandung: Citra Aditya Bakti. 2010.

Wahbah Zuhayli. Al-Fighul Islami wa Adilatuhu IX. Damaskus: Daar alFikri.1404. 